\title{
Determinants of Nominal Effective Exchange Rate in Uganda (2000-2017): A Vecm Approach
}

\author{
Sawuya Nakijoba \\ Correspondence: Sawuya Nakijoba, Capacity Development Division, United Nations Economic Commission for Africa, \\ P. O Box 3001, Addis -Ababa, Ethiopia.
}

\author{
Received: July 15, $2018 \quad$ Accepted: August 6, $2018 \quad$ Available online: August 16, 2018 \\ doi:10.11114/aef.v5i5.3543 URL: https://doi.org/10.11114/aef.v5i5.3543
}

\begin{abstract}
$^{1}$
This study analyses the main determinants of the nominal effective exchange rate using quarterly time series data covering the period 2000 to 2017. The Augmented Dickey Fuller test confirms that all the with the exception of interest rate were non stationary in levels. This study employs the reduced form Vector Auto-regression (VAR) and Johansen and Juselius cointegration to estimate the long run relationship between exchange rate and other key variables. The VAR is used following the Mundell-Fleming model which argues that, in an open economy with external trade and financial transactions the key macro variables interact and influence each other with lags. The impulse response functions are used to investigate the monetary policy transmission mechanism (MPTM). The study indicates that money supply, terms of trade and inflation were negative while gross domestic product and interest rate were positively related to exchange rate. The variables were found to have a long run relationship. The estimate of the speed of adjustment indicates that when nominal effective exchange rate deviates from the equilibrium, it returns to the equilibrium quickly because of its coefficient of adjustment which is 0.25 .
\end{abstract}

Keywords: exchange rate, VAR, VECM, MPTM, Mundell- Fleming model, Johansen and Juselius cointegration JEL Classification: C32, E52, G14

\section{Introduction}

The exchange rate is an important price in an economy, which not only influences business decisions but also affects the competitiveness of the domestic traded goods sector in an economy (Kandil, 2004). Exchange rates play a major role in foreign trade in terms of determination of prices, of goods and services produced in different countries, quote debts, money transfers and, above all, they represent the main equilibrator of a country's trade and balance of payments. Because of their strong influence on the current account and several macroeconomic variables, exchange rates are among the most significant price competitiveness indicator in an open economy. It becomes therefore crucial to understand the main determinants of exchange rates whose movements are determined by the interactions of households, firms and financial institutions (Jhingan, 2005).

Uganda's nominal effective exchange rate has not been stable over time. In the fiscal year 2014/15, the Ugandan Shilling (UGX) depreciated against the US dollar by 27 per cent. Over the past decade, the worst depreciation rate was recorded in October, 2008 where the shilling depreciated against the dollar from UGX 1,645 in September 2008 to UGX 1,838.73 in October 2008 and the rate of depreciation was noted to be $11.8 \%$ (Civil society budget advocacy group, 2016). This trend could perhaps be linked both the global financial and economic crisis of 2007/2008 and also to the seasonality of the demand for the United States Dollars (USD) towards Christmas and Easter holidays as traders' and other players in the market stock goods and services. Importers and those who wish to travel abroad buy the USD just before of the festive seasons so that they do not face the high rate. This development in its self is self-correcting since the shilling appreciates after this period. The developments witnessed from July 2014 to February 2015 where the shilling slowly but steadily depreciated against the USD can be explained by a number of reasons with the strongest of them pointing to reduction in the supply of the USD on the world market. From December 2016 to December 2017 the exchange rate increased from UGX 3557 to UGX 3631 implying depreciation of the shilling relative to the USD.

\footnotetext{
${ }^{1}$ Disclaimer: The views expressed in this paper are those of the author and do not necessarily reflect the Position and Policies of the United Nations Economic commission for Africa (UNECA)
} 
This paper builds on this previous work by looking at the macro-economic determinants of nominal effective exchange rate. Specifically, this paper investigates the long run relationship among the variables as well as the monetary policy transmission channels for Uganda. This paper contributes to literature by taking a different approach in addressing the factors that drive the nominal effective exchange rate in Uganda. Much as some Uganda specific studies capture the determinants of exchange rate, there is a big gap left to cover and hence it is the background motivation of this paper. For example, Mayambala (2016) studied the impact of capital inflows on real exchange rate in Uganda. He used Ordinary least estimation (OLS) technique and annual data from 1987-2000 but never included dummy variables to capture the structural breaks in the data like in 2008 during the global economic crisis, among others. Also There is also a big gap between when the paper was written and published. In my own thinking, a lot of changes took place in Uganda between 2000 and 2016. This paper therefore departs from the rest by using one of the recent econometric technique, that is, a VECM approach and also recent quarterly data spanning from 2000-2017.

The rest of the paper is structured as: Section Two, presents the literature regarding the determinants of the nominal exchange rate in Ugandan time series; Section Three presents the stipulations of nominal effective exchange rate based on VAR and VECM Methodology; Section Four presents the data qualities while Section Five presents the paper's results and interprets the intuition behind them. Lastly, Section Six concludes and provides policy insights.

\section{Literature Review}

Over the past two decades, many developing countries world over have shifted away from fixed exchange rate regimes towards more flexible exchange rate regimes (Opolot,2018). In Uganda, a flexible exchange rate regime with a two-window system was introduced in August 1992 (Kasekende and Atingi, 1995) and implemented in the early 1993. Window 1 was a managed float system mainly for foreign exchange proceeds from traditional exports, central bank loans and foreign exchange for debt servicing. The second window exchange rate was determined at weekly auctions of foreign exchange by the central bank and it was for all other transactions. Uganda's regime has been classified in the bank of Uganda Annual report on exchange arrangement and Exchange Restrictions (AREAER) as "independently floating" since 1992.Consistent with this classification, the Bank of Uganda describes its exchange rate policy as one in which it intervenes in the foreign exchange market only to stem volatility, with no medium-term exchange rate target (Abuka et al., 2015).

This paper is motivated by a plethora of theories that try to explain the determinants of exchange rate. The study is guided by the Mundell Fleming model, Edward Sebastian model, Purchasing Power Parity (PPP) and Real Interest rate theory of exchange rate. The Mundell-Fleming model by Robert Mundell and Marcus Fleming (1963) considers the determination of the exchange rate and how the exchange rate affects imports and exports. It typically assumes that capital may move freely and that investments will flow to countries where the return is maximized. The model is basically an extension of the neo-classical synthesis with a model for the exchange rate that allows for free capital flows. The model portrays the short-run relationship between an economy's nominal exchange rate, interest rate, and output (in contrast to the closed-economy IS-LM model, which focuses only on the relationship between the interest rate and output). Sebastian (1989) model states that the fundamental determinants of the Exchange Rate are those real variables that play a large role in determining the country's internal and external equilibrium. The external fundamentals include: international prices (international transfers, including foreign aid flows and world real interest rates. The domestic exchange rate fundamentals can be divided into those variables that are policy related (like import tariffs, import quotas and export taxes) and those that are independent of policy decisions. He argues that, although the equilibrium Exchange rate is a function of real variables only, the actual real exchange rate responds both to real and monetary Policy and variables.

The PPP is the simplest concept of law of one price (LOOP). Assuming non-existence of tariffs and other trade barriers and zero cost of transport, the law states that identical goods should cost the same in all nations. Therefore, prices of goods sold in different countries, converted to a common currency, should be identical. The theory states that in countries following fluctuating exchange rates, equilibrium will occur when these countries hold similar buying power. This involves the fact that if any one of the countries has a greater price level, the home currency of that country will be facing a depreciation in exchange rates (Syed and Sahar, 2017). Interest rate theory of exchange rate introduces interest rate differentials. The connection between currency exchange rates and interest rate differentials appeared after the end of the Bretton Woods agreement in 1970-1972. The theory assumes that interest rate differential between two countries remains always equal to the differential calculated by using the forward exchange rate and the spot exchange rate. If other factors are held constant the higher returns from high interest rates attracts investors and hence increases capital inflow (Bailliu et al., 2005).

Empirically, voluminous researchers and economists determine nominal effective exchange rates with diverse approaches and theories. None of them provided the exact parameter to foresee the determinants of exchange rates in all environments. There are fundamental and non-fundamental determinants and their effects are inconclusive, that is: the 
effect can have a positive effect; negative effect; both positive and negative effects; or no significant effect on exchange rate.

Inflation rate: As a general rule, a country with a consistently lower inflation rate exhibits a rising currency value, as its purchasing power increases relative to other currencies. During the last half of the 20th century, the countries with low inflation included Japan, Germany and Switzerland, while the U.S. and Canada achieved low inflation only later. Those countries with higher inflation typically see depreciation in their currency in relation to the currencies of their trading partners. Raja (2014) Reheman (2010) all found out inflation is positively related to exchanger rate, contradicting with Achsani (2010) for the study conducted in Asia. This variable was included in the study because of the argument by Kulkarni and ishizaki (2002) in their study about Purchasing power parity theory revisited with from US Dollar and Japanese Yen. They argue that higher inflation rates minimize the competitiveness of the country in the international market which in turn decreases the country's exports resulting into a decline in the demand for the local currency thereby lowering the value of the home currency (Mugume, 2011).

Interest Rates rise tend to attract foreign investment, increasing the demand for and value of the home country's currency (appreciation) according to Interest rate theory of exchange rate. Utami and Inanga (2009) in an Indonesian study about the impact of interest rate differentials on the exchange rate against four countries namely Japan, Singapore, United Kingdom and United States of America. The study found out that interest rate differentials had a significant negative effect on the Indonesian exchange rate against Japan and for other three countries the relationship between interest rate differentials and exchange rate was positive and insignificant. This was in line with the findings of Taoufik et al., (2015) in Thailand. They identified interest rate differentials, manufacturing production index, international reserve, government debt, terms of trade, monetary base to be the key variables to explain exchange rate movements and they found out that interest rate differentials had negative and significant effect in determining $\mathrm{g}$ the exchange rate between Thailand's currency (Thai baht) against the USD.

Gelbard and Nagayasu (2004) studied the determinants of exchange rate in Angola (1992-2002) using Ordinary least square technique and they found out that interest rate was negative and significantly causing a variation in the country's flexible exchange rate system. The negative sign was also found by Rehman (2010) and Effiong (2014). The negative sign shows that when there is an increase in the interest rate of the economy, foreign direct investment will be attracted in the economy which will in turn help in the appreciation of the local currency exchange rate against the foreign currency which is in line with the Mundell-Fleming model .However following the Asian crisis the relationship between real interest rate and real exchange rate is hotly debated for example Furman and Stiglitz (1998) who examined the effect of increase in interest rate, inflation and non-monetary factors on exchange rate of 9 developing countries (1992-1998). They found that high interest rate was associated with a subsequent depreciation of the nominal exchange rate but the effect was more pronounced in low inflation countries than the high inflation countries. In this study interest rate (INT) is proxied by three months (91 days) treasury bill measured in percentages and this is the short term interest rate used by the central bank of Uganda (Montiel, 2013).

Terms of Trade (TOT) defined as the ratio of export prices to import prices is another determinant of exchange rate If the term of trade increases it will raise the purchasing power of people and this results in an increase in the demand for domestic goods (Raghuram, 2006). Joyce and Kamas (2003) analyzed the factors that determine the long-run real exchange rate in Argentina, Colombia and Mexico between 1971-1995, distinguishing between real and nominal determinants. Cointegration analysis was utilized to establish that the real exchange rate has an equilibrium relationship with real variables (the TOT, capital flows, productivity, and government share of GDP) which excludes nominal variables (nominal exchange rate, money) and central bank intervention). Variance decompositions reveal that among the real variables that determine the real exchange rate, the terms of trade explain much of the variation in the real exchange rates and it is negatively related. The same findings were supported by Zakaria et al. (2011) in Pakistan.

Kumar (2010) investigates the determinants of exchange rate in India using ARDL approach using quarterly from 1997 to 2009 QII and concluded that TOT has a negative effect on the real exchange rate. In a similar study by Bergval (2004) with major emphasis on Terms of trade, the study investigated the contributing factor of real exchanger rate in four Nordic countries except Finland and it was found out that TOT variable was crucial and significant in influencing the long term movement in exchange rate. Oskooee et al (2006) found out that improvements in terms of trade greatly improve the domestic currency. He argues that, however, if the improvement is from increased exports prices there will be depreciation in the exchange rate. The findings were from the determinants of exchange rate of 38 African countries during 1970-1990 using a panel regression. However, Milesi-Feretti and Lane (2010) found no significant effect of terms of trade on exchange. In this study the TOT is defined as the ratio of export to import price as a percentage of GDP.

Money supply: Abundant money supply reflects the accessibility of funds in the market to purchase goods and services. In order to meet this excess demand, manufacturers will employ more workers. This will raise the cost of output and subsequently resulted in higher prices to meet the extra cost of manufacturing (Syed Ali Raza and Sahar Afshan ,2017). 
Higher price level ends up in devaluation of home currency Khattak et al., 2012). Abbas et al (2011) argue that, an increase in money supply cuts down the interest rate by making money easily available and cheaper to acquire resulting into depreciation of the domestic currency (Nampewo et al, 2013). In this study we use the broad money supply (M2).

Gross domestic product is another key determinant of exchange rate. This variable is used to proxy the economic growth of the economy. Mixed results have been produced about the effect of GDP on real exchange rate. Patosa and Cruz (2013) investigated about the factors affecting exchange rate movements in selected Asian countries namely China, Malaysia, Thailand, Philippines and Singapore using the data that came from the World Bank for the period 1977-2010 and it was found out that GDP increases, real exchange rate appreciates. The same results were also found out by Naeem et al., (2012). Mirchandani (2013) analyzed the determinants of macro-economic exchange rate volatility in India using data the reserve bank of India from 1991-2010 and also found a negative impact of GDP on exchange rate. However, Harberger (2003) in the study about the impact of economic growth on real exchange rate proxied by real GDP found no systematic connection between the two variables.

International oil prices: A wide variety of studies have analyzed the impacts of oil price changes on macroeconomic variables for many countries with different economic characteristics since global financial integration has become widely prevalent. For many European countries, Cunado and Garcia (2003) found that an oil price increase had permanent effects on inflation and asymmetric effects on production growth rates. For the case of China, Tang et al. (2010) showed that increases in oil prices affected output and investment negatively Similarly, Qianqian (2011) revealed that rising oil prices would cause the real output to decline and the prices to ascend in China. Parallel results were also obtained for the US economy by Kilian (2008) and Kilian and Vigfusson (2011), who detected a negative impact of oil price increases on the real GDP and inflation. According to Balke et al. (1999), increases in oil prices influenced the output via interest rates in the US; more precisely, oil prices influenced the interest rates asymmetrically before they affected the output asymmetrically. Jiménez-Rodríguez and Sánchez (2010) stated that oil price increases prompt to a decrease in industrial production and higher inflation based on their study for Japan.

The effects of oil price changes on economic activity may also differ depending on whether the country is an oil importer or an oil exporter. According to Mendoza and Vera (2010), there have been asymmetric effects of oil price increases on output growth in oil exporters, thus the unexpected rise in oil prices impacts the economy positively. Jiménez-Rodríguez and Sánchez (2004) found that increases in oil price had a negative impact on economic activity in importing countries, except for Japan, whereas the oil price increases affected the UK negatively and Norway positively. The effects of oil price changes on macroeconomic variables may also differ according to the level of economic development. Eryigit (2009) studied the 1973 and 1979 oil price changes' effects on the developed and developing countries. The findings of this study implied that low income countries were affected more seriously than countries with high income. Also, they explained that the effect varies according to the level of dependency on energy sources, development degree and capital intensity degree of the economy. Eryigit (2012) stated that changes in oil prices mostly affect emerging economies rather than developed economies. In other words, they emphasized that there is a correlation between oil price changes and industrial development.

\section{Methodology}

After reviewing the theoretical and empirical work, the model to examine the determinants of nominal effective exchange rate in Uganda was adopted and modified from Raza and Afshan (2017) in the study about the determinants or exchange rate in Pakistan. We formulate the determinant of nominal exchange rate in Uganda as:

$$
E R_{t}=f\left(I N T_{t}, I N F_{t}, T O T_{t}, M 2_{t}, G D P_{t} O I L P X_{t}, \varepsilon_{t}\right)
$$

Where: ER is the Nominal effective exchange rate given by the Uganda shillings to United States Dollar, that is UGX/ USD. INT is the interest rate or the three months (91days) treasury bill measured in percentages and this is the short term interest rate used by the central bank of Uganda. M2 is the broad money supply. INF is inflation proxied by core consumer price index (CPI). GDP is gross domestic product and OILPX is the international oil price. TOT is the terms of trade or the ratio of price of exports to price of imports. and is the stochastic error term that is assumed to be distributed with zero mean $\mu_{i}$ and constant variance $\delta_{i}^{2}$ that is,

$$
\varepsilon_{t} \rightarrow \text { i.i.d }\left(0, \delta^{2}\right)
$$

Equation (1) could be estimated by a simple OLS. However, OLS assumes a single equation model where the dependent variable $\mathrm{Y}$ is influenced by a set of independence variables. Sims (1980) argues that most macroeconomic time series variables are endogenous, that is, they influence each. He also argues that the variables in the current period depend on the previous value hence monetary policy variables have to be modelled with lags. To improve the Raza and Afshan (2017) and obtain more consistent results, this study investigates macroeconomic determinants of exchange rate in Uganda (2000-2017) using a reduced form VAR and VECM approaches. The group of endogenous variables Y includes the INF, GDP), EX, INT and M2. These variables are assumed to influence each other with their own lags and 
lags of other endogenous variables, current values of the exogenous variable. The reduced-form of VAR model used in this study was adopted and modified form that of Tran (2018) and presented as:

$$
Y_{t}=A_{0}+\sum_{i=1}^{k} A_{t} Y_{t-i}+\varnothing X_{t}+\varepsilon_{t}
$$

Where $Y_{t}$ and $Y_{t-i}$ are both (jx1) column vectors with $\mathrm{j}$ as number of endogenous variables, Yt includes observations at time $\mathrm{t}$ and $\mathrm{Y}_{\mathrm{t}-\mathrm{i}}$ includes $\mathrm{i}$-th lagged value of endogenous variables. $\boldsymbol{A}_{\mathbf{0}}$ denotes a (jx1) vector of intercept terms, while $\mathrm{Xt}$ indicates an $(\mathrm{mx} 1)$ column vector of $\mathrm{m}$ exogenous variables. $\boldsymbol{\varepsilon}_{\boldsymbol{t}}$ is a (jx1) vector of disturbance terms. When I (1) variables are cointegrated, the VAR model can be expressed by first difference error correction form as:

$$
\Delta \mathrm{Y}_{\mathrm{t}}=\mathrm{A}_{0}+\pi \mathrm{Y}_{\mathrm{t}-\mathrm{i}}+\sum_{\mathrm{i}=1}^{\mathrm{k}} \mathrm{A}_{\mathrm{i}}^{*} \Delta \mathrm{Y}_{\mathrm{t}-1}+\varnothing \mathrm{X}_{\mathrm{t}}+\varepsilon_{\mathrm{t}}
$$

Where $\Delta \mathrm{Yt}$ is the first difference of Yt. $\boldsymbol{\pi}$ is coefficient matrix containing information on long-run relationship among Yt. $\boldsymbol{i}=\mathbf{1}, \ldots, \mathrm{k}$ is the lag-length, which is sufficient to remove any remaining serial correlation in the model. $\boldsymbol{\Pi}$ is a long-run matrix which according to Johansen (1988) can be written as, $\boldsymbol{\Pi}=\boldsymbol{\alpha} \boldsymbol{\beta}^{\prime}$ with $\boldsymbol{\alpha}$ and $\boldsymbol{\beta}$ both being matrices of dimensions (k x r). The rank $\boldsymbol{\pi}$ written as $\boldsymbol{\pi}=\boldsymbol{\alpha} \boldsymbol{\beta}^{1}$ reflects the number of cointegrating relations (r). $\boldsymbol{\alpha}$ and $\boldsymbol{\beta}$ are both (jxr) matrix. The coefficient $\boldsymbol{\alpha}_{\mathrm{i}}$ measures the speed of adjustment of exchange rate towards the equilibrium, while $\boldsymbol{\beta}^{1}$ denotes the long-run estimator of that variable known as the cointegrating vectors. Matrix $\boldsymbol{A}_{\boldsymbol{i}}^{*}$ contains information on short-run dynamics in cointegrated system. The VECM can deal with I (1) variables without taking the first difference, when the variables are cointegrated. It therefore preserves multiple cointegrating relationships in the system and then avoids the issue of misspecification (Enders, 2010). The VECM expresses the VAR in I (0) space, i.e. the dependent variable exchange rate is now $\Delta \mathrm{Y} \boldsymbol{t} \sim \mathbf{I}(\mathbf{0})$ and $\Delta \mathrm{Y} \boldsymbol{t}-\mathbf{1} \sim \mathbf{I}(\mathbf{0})$, which facilitates standard hypothesis testing. The VECM helps us see the short run dynamics of the model. It enables us determine the speed of adjustment from short run to long run equilibrium.

\section{Estimation procedure and technique}

The study uses E-views version 9 in the estimation. The first step involves preliminary analysis to study the behavior of variables using the descriptive statistics and adjustments for seasonal effects /bias. Economic analysis is focused on business cycles. The data this study uses is a quarterly frequency and spans for 18 years, making it a suitable candidate for seasonal effects adjustment. In applied time series, it is a common suspicion that quarterly gross domestic product, inflation, money supply series are embedded with strong seasonal components. As such performing an analysis on variables with seasonality is a recipe for incorrectly characterizing cyclical behaviour, and the ensuing results would be spurious (Bwire et al.,2013). Testing and adjusting the series for seasonality effects was done using the popular X12 method by the Census Bureau of Statistics which is available only for monthly and quarterly series.

The unit root test is carried out before running the model to avoid spurious regression, as Brooks (2008) insists. A variable is stationary if the null hypothesis of a unit root is rejected. Random walk process is the major source of non-stationarity. Taking the first difference removes both types of trend-like behavior time trend should be included, because the exchange rate and oil price seem to steadily rise over time. The standard Augmented Dickey-Fuller (ADF) unit root test was used to examine the stationary properties for the long run relationship of the times series variables. The Augmented Dickey-Fuller (see Dickey and Fuller, 1979) test is given by:

$$
\Delta Y_{t}=\alpha_{0}+\beta_{t}+\alpha_{1} Y_{t-1}+\sum_{j=1}^{k} d_{j} \Delta Y_{t-j}+\varepsilon_{t}
$$

Where: $\varepsilon$ is the white noise error term, $\Delta$ is the first difference operator, $\mathrm{Y}$ is the times series, $\alpha_{0}$ is the intercept and $\mathrm{k}$ is the optimum number of lags of the dependent variable. Imposing the constraints that alpha and beta are equal to zero corresponds to modelling a random walk and using the constraint beta is equal to zero corresponds to modeling a random walk with a drift. $\alpha=0\{$ \displaystyle $\backslash$ alpha $=0\} \beta=0\{$ \displaystyle $\backslash$ beta $=0\} \beta=0$ \displaystyle $\backslash$ beta $=0\}$ The variable is said to be stationary if the value of the coefficient $\alpha_{1}$ is less than the critical values from ADF table.

Then determination of optimal lag length is done. When choosing the lag-length (the lag at which the residuals are free from serial correlation), we want to reduce the number of lags as much as possible to get as simple a model as is possible, but at the same time we want enough lags to remove autocorrelation of the VAR residuals. The appropriate lag-length $(\rho)$ of the VAR are chosen using the Akaike information criterion (AIC), Schwarz Bayesian information criterion (SBC) and Hannan Quinn (HQ) information criteria. These criteria have the same basic formulation, i.e. derive from the log likelihood ratio (LR) function but penalize for the loss of degrees of freedom due to extra $\rho$ lags to different degrees, hence, in practice, need not to select the same preferred model and often they do not.

Juselius (2006) gives a very detailed exposition of these frameworks. AIC asymptotically over estimates the order with positive probability, HQ estimates the order consistently and SBC is even more strongly asymptotically consistent (Bwire, 2018), i.e., it selects a shorter lag than the other criteria hence the reason why, in applied work SBC is usually favoured in choosing the appropriate order of VAR. This notwithstanding, it is very important to note that the residuals from the estimated VAR should be well behaved, i.e., there should be no problems with autocorrelation and 
heteroscedasticity. hence, the AIC, SBC or HQ may be good starting points for determining the lag-length of the VAR. This study checks for residual autocorrelation using the LM test.

VAR Residual statistical properties. It is also important, upon establishing the true order of VAR, to assess the suitability of the choice model in terms of a battery of residual misspecification tests (Godfrey, 1988). This study uses the residuals plots for the residual normality test. The idea with residual plots is to see if there are outlier observations and /or change in behaviour over time. Such features, if detected, can be dealt with by taking appropriate modelling actions, to account for such outlier observations or mean shifts using the dummies particularly in the interest of preserving the degrees of freedom.

Stability of VAR /Roots of the polynomial: The study checks the stability of the VAR. If the VAR is not stable, certain results (such as impulse response standard errors) are not valid. In doing this procedure, there will be $(\mathrm{n} \times \mathrm{p})$ roots overall, where $n$ is the number of endogenous variables and $p$ is the particular lag length. The VAR is said to be stable if none of the roots lie outside the unit circle. This means that all the moduli of the roots of the characteristic polynomial are less than one in magnitude.

Cointegration analysis: After the results of ADF indicating that the series were stationary, the study estimates the long run relationship using the technique developed in Johansen (1988) and applied in Johansen and Juselius (1990). The test uses the Trace and Max Eigen test Statistic to identify the number of cointegrating variables. The test is conducted under the null hypothesis that there is no long run relationship among the variables. This system approach sets up a non-stationary time series as a Vector Autoregressive (VAR) process of order $\rho$ in a re-parameterized form.

$$
\begin{gathered}
J_{\text {trace }}=-T \sum_{i=r+1} \ln (1-\hat{\lambda}) \\
J_{\max }=-T \ln \left(1-\hat{\lambda_{r+1}}\right)
\end{gathered}
$$

Where $\mathrm{T}$ is the sample size and $\hat{\lambda}$ is the estimated eigen values and $\ln$ is the natural log. The trace tests the null hypothesis of $r$ cointegrating vectors against the alternative hypothesis of $n$ cointegrating vectors while the maximum eigen value tests the null hypothesis of $r$ cointegrating vectors against the alternative hypothesis of $r+1$ cointegrating vectors. In most cases the trace is preferred to the max eigen test. However, the trace test suffers from infinite sample bias. The sample bias adjustment is done using the correcting procedure suggested by Reimers (1992) and Harris and Sollis (2005).

\section{Data}

$$
\mathrm{J}_{\text {trace\# }}=-(T-n k) \sum_{i=r+1}^{n} \ln (1-\lambda)
$$

This analysis of this paper is constrained by paucity of data hence it uses quarterly time series data on the Ugandan Macro-economic variables for the period 2000: QI -2017: QIII. All variables are expressed in logarithms, except the treasury bills rate which is a percentage. The aim is to normalize them, reduce outliers and interpret as elasticities. The data were obtained from Bank of Uganda (2018) and Uganda Bureau of Statistics (2018).

\section{Results and Discussions}

We adjusted for seasonality since we were using quarterly data for GDP, oil price, Core CPI and M2. Exchange rate was not adjusted given its nature in Uganda. The variable is a random walk and members are rational in making their expectations since the market function is built on speculation.

Table 1. Adjustment for Seasonal bias

\begin{tabular}{l|l|l}
\hline Variables & Probability & Conclusion \\
\hline GDP & 0.000 & Seasonality present \\
\hline Core CPI & 0.001 & Seasonality present \\
\hline M2 & 0.000 & Seasonality present \\
\hline Int rate & 0.058 & Seasonality present \\
\hline Oil price & 0.000 & Seasonality present \\
\hline
\end{tabular}

H0: seasonality component in series

From the table above seasonality was present in all the series hence we use the seasonally adjusted (_sa) variables in this study. 
Table 2. ADF unit root test results

\begin{tabular}{|c|c|c|c|c|c|c|c|c|c|}
\hline \multirow{3}{*}{ Variables } & \multicolumn{4}{|r|}{ Levels } & \multicolumn{4}{|c|}{ First difference } & \multirow[t]{3}{*}{ Order of int } \\
\hline & \multicolumn{2}{|l|}{ intercept } & \multicolumn{2}{|c|}{ Inter\& trend } & \multicolumn{2}{|l|}{ intercept } & \multicolumn{2}{|c|}{ Int \& trend } & \\
\hline & Test stat & $5 \%$ & Test stat & $5 \%$ & Test stat & $5 \%$ & Test stat & $5 \%$ & \\
\hline ER & -0.048 & -2.904 & -2.026 & -3.476 & -6.465 & -2.904 & -6.460 & -3.478 & I (1) \\
\hline GDP & -1.797 & -2.904 & -1.721 & -3.476 & -18.923 & -2.904 & -19.286 & -3.478 & $\mathrm{I}(1)$ \\
\hline M2 & -1.230 & -2.904 & -0.795 & -3.476 & -9.205 & -2.904 & -9.371 & -3.478 & $\mathrm{I}(1)$ \\
\hline INT & -3.279 & -2.904 & -4.958 & -3.476 & & & & & $\mathrm{I}(0)$ \\
\hline CPI & -0.187 & -2.904 & -2.196 & -3.476 & -4.196 & -2.904 & -4.142 & -3.478 & I (1) \\
\hline TOT & -2.091 & -2.906 & -3.287 & -3.480 & -8.590 & -2.907 & -8.551 & -3.480 & $\mathrm{I}(1)$ \\
\hline Oilpx & -1.642 & -2.904 & -1.207 & -3.476 & -6.842 & -2.904 & -6.902 & -3.478 & I (1) \\
\hline
\end{tabular}

We fail to reject the null if the test statistics of the ADF $>5 \%$ critical value.

From table 2, all the variables (except the three months interest rate) are stationary, that is, integrated of order one I(1). This means that such series were differenced once to make them stationary, that is, integrated of order zero (I (0)

Determination of lag length for the VAR: The reduced form VAR is not economically intuitive hence estimated coefficients are not interpreted with economic sense. They are spurious with high R-Squared and very high t- ratios. Instead the results from this VAR aids us to get an appropriate VAR specification in terms of the number of lags.

For 4 lags, FPE, AIC choose 4 lags, HQ choose 2 lags and SBC choose only one lag. All these criteria have different penalties, SBC is preferred. The study then tested for serial correlation in the residuals that is, the number of lags at which the residuals are free from serial correlation.

Table 3. Lag length for the VAR

\begin{tabular}{c|c|c|c|c|c|c}
\hline Lag & LogL & LR & FPE & AIC & SC & HQ \\
\hline 0 & 358.0857 & NA & $1.31 \mathrm{e}-12$ & -10.33092 & -9.936046 & -10.17467 \\
\hline 1 & 745.6237 & 682.5296 & $3.67 \mathrm{e}-17$ & -20.82459 & $-19.24511^{*}$ & -20.19958 \\
\hline 2 & 803.9246 & 92.23737 & $1.94 \mathrm{e}-17$ & -21.49029 & -18.7262 & $-20.39653^{*}$ \\
\hline 3 & 827.6514 & 33.28823 & $3.02 \mathrm{e}-17$ & -21.12392 & -17.17522 & -19.56141 \\
\hline 4 & 895.5113 & $83.05252^{*}$ & $1.35 \mathrm{e}-17 *$ & $-22.07497^{*}$ & -16.94165 & -20.0437 \\
\hline
\end{tabular}

Residual serial correlation Lm

The study included 4 lags to accommodate all the selection criteria above. This was tested under the null hypothesis of no serial correlation in the residuals.

Table 4. Residual serial correlation Lm

\begin{tabular}{ccc}
\hline Lags & LM-Stat & Prob \\
\hline & & \\
1 & 55.16497 & 0.0214 \\
2 & 63.29039 & 0.0033 \\
3 & 40.29848 & 0.2858 \\
4 & 70.64183 & 0.0005 \\
\hline
\end{tabular}

From the table above, it is at lag three (3) that there is no serial correlation in the residuals. At Lag three we fail to reject the null hypothesis of no serial correlation in the residuals.

Table 5. VAR (3) roots of the characteristic Polynomial

\begin{tabular}{cc}
\hline Root & Modulus \\
\hline & \\
0.979752 & 0.979752 \\
$0.785588-0.396265 \mathrm{i}$ & 0.879871 \\
$0.785588+0.396265 \mathrm{i}$ & 0.879871 \\
0.875171 & 0.875171 \\
$-0.054113+0.841294 \mathrm{i}$ & 0.843033 \\
$-0.054113-0.841294 \mathrm{i}$ & 0.843033 \\
-0.753907 & 0.753907 \\
$0.671639-0.177435 \mathrm{i}$ & 0.694682 \\
$0.671639+0.177435 \mathrm{i}$ & 0.694682 \\
$0.437109-0.467259 \mathrm{i}$ & 0.639840 \\
$0.437109+0.467259 \mathrm{i}$ & 0.639840 \\
$0.255328-0.529486 \mathrm{i}$ & 0.587833 \\
$0.255328+0.529486 \mathrm{i}$ & 0.587833 \\
-0.535438 & 0.535438 \\
$-0.004462-0.517301 \mathrm{i}$ & 0.517320 \\
$-0.004462+0.517301 \mathrm{i}$ & 0.517320 \\
$-0.313955-0.283147 \mathrm{i}$ & 0.422777 \\
$-0.313955+0.283147 \mathrm{i}$ & 0.422777 \\
\hline
\end{tabular}


Stability of VAR (3): This helps to test whether the VAR falls within the unit cycle. If a VAR is stable, none of the roots lies outside the unit circle then response standard errors are valid hence we can make predications on it. The total number of roots is 18 (six endogenous variables multiplied by 3 lags).Since all the moduli of the roots of the characteristic polynomial are less than one in magnitude, it implies that no root lies outside the unit circle hence VAR satisfies stability condition.

VAR residual heteroscedasticity test: Having found out that at lag 3, residuals are free from serial correlation, the study tests for the residual heteroscedasticity to ascertain whether the residuals are free from the problem of heteroscedasticity. The VAR Residual Heteroskedasticity Tests (no Cross Terms) indicates that the chi square value is 355.9083 with the probability of 0.1565 . This means that we fail to reject the null hypothesis that residuals are not heteroscedastic and conclude that there is homoscedasticity in the residuals.

Johansen and Juselius Cointegration test: Having obtained the optimal number of lags and confirming that most series are Non-stationary, the Johansen Co-integration test was used to find out the long run relationship between the study variables. The Johansen and Juselius cointegration was preferred to the Engle -Granger method which assumes single equation because of the nature of the variables in this study. Variables are endogenous meaning that the number of equations is equal to the number of variables.

Table 6. Johansen and Juselius cointegration test results

\begin{tabular}{cccccc}
\hline $\begin{array}{c}\text { Hypothesized } \\
\text { No. of CE(s) }\end{array}$ & $\begin{array}{c}\text { Trace } \\
\text { Statistic }\end{array}$ & $\begin{array}{c}0.05 \\
\text { Critical Value }\end{array}$ & $\begin{array}{c}\text { Max-Eigen } \\
\text { Statistic }\end{array}$ & $\begin{array}{c}0.05 \\
\text { Critical Value }\end{array}$ & $\begin{array}{c}\text { Trace } \\
\text { Stat \# }\end{array}$ \\
\hline None * & 147.1083 & 95.75366 & 61.64611 & 40.07757 & 104.3994691 \\
At most $1 *$ & 85.46222 & 69.81889 & 37.95388 & 33.87687 & 60.65058521 \\
At most 2 & 47.50834 & 47.85613 & 29.66112 & 27.58434 & 33.71558597 \\
At most 3 & 17.84722 & 29.79707 & 9.236273 & 21.13162 & 12.66575611 \\
At most 4 & 8.610947 & 15.49471 & 4.982407 & 14.26460 & 6.110975898 \\
At most 5 & 3.628540 & 3.841466 & 3.628540 & 3.841466 & 2.575084196 \\
\hline
\end{tabular}

Trace stat \# are personal computations by the author

Both the trace indicates two while the maximum eigen tests indicate that there are three cointegrating equations at $0.05 \%$. Since the trace is more superior to the maximum eigen values., this relies on the trace statistics. The trace statistics suffers from sample bias and were computed using the formula specified in equation (8) and values represented as trace stat \# in the table (6).

Based on the results, the presence of two equilibrium (stationary) relations, even when corrected for small sample bias among the variables at the conventional 5 percent level of significance cannot be rejected. However, we know that interest rate is I (0) while the rest of the variables are I (1). Intuitively only one cointegrating equation was making sense. The second was spurious with an identity formed. This implies that potentially, the I (0) variable may have added an additional cointegrating relation in the model. Thus, adjusting the number of cointegration equations for the one I (0) variable leaves only one long-run relationship specified

Table 7. Estimation of the Johansen cointegration equation

\begin{tabular}{c|c|c|c|c|c}
\hline LEXR & LCPI & LGDP & LM2 & LTOT & LIR \\
\hline 1.000000 & -18.995 & 9.501 & -1.588 & -14.840 & 9.877 \\
\hline N/A & $(1.51605)$ & $(0.7863)$ & $(0.0991)$ & $(6.77384)$ & $(1.99743)$ \\
\hline t-values & 11.85 & 13.37 & 16.05 & 2.219 & 4.96 \\
\hline
\end{tabular}

standard error in parentheses. A positive sign means appreciation of the UGX and a negative means depreciation

It can be seen that all the variables are significant in explaining variation in the nominal effective exchange rate of Uganda. Inflation measured by core consumer price index, broad money supply (M2) and terms of trade are negatively related to exchange rate. This means that a unit increase in inflation will result into a18.99 units' depreciation of the exchange rate. Inflation means that there is too much money chasing too few goods and services, the currency loses its value hence depreciation.

A unit increase in money supply depreciates the exchange rate by 1.5 units. The excessive supply of money cuts down the interest rate by making money easy and cheap to acquire. This creates depreciation on the local currency. Also too much supply of money causes the availability of funds in the market to buy goods and services. To meet this additional demand, producers employ more workers and end up with increased cost of production. The scenario pushes the prices to go up, decreases the global competitiveness and results in depreciation of home currency (Bleaney and Fielding, 2002. As the terms of trade worsens meaning Uganda's import prices up and export prices go down, then the exchange 
rate depreciates by 14.84 units, holding all other factors constant. This is because it makes exports are cheap while imports are expensive, the overall balance of payment worsens hence depreciation of the Uganda shillings

The three months' interest rate measured by the 91 days' treasury bill and Gross domestic product are positive but significant. This means that, with all other factors constant, a unit increase in interest rate is associated with a 9.877unit appreciation of the exchange rate. This is because a higher interest rate provides higher rates to lenders there by attracting more foreign capital which causes an appreciation in the exchange rate. The higher interest rate means that savings locally gives more returns. The investors often move funds to such countries (This is known as hot money flows). As GDP increase by one unit, holding all other factors constant, the exchange rate increases/appreciates by 9.5 units. The increase in GDP means that economic growth is attained due to improvement in technology, accumulation of capital and improvement in quality of labour.

The existence of cointegration lead us to conducted a Vector Error correction model (VECM). The VECM to help us see the short run dynamics of the model. It enables us determine the speed of adjustment from short run to long run equilibrium. They directly estimate the speed at which a rate returns to equilibrium after a change in other variables. The coefficient of the error correction term is -0.2591 and it carries the correct(negative) sign and is statistically significant. When the nominal effective exchange rate deviates from the equilibrium, its adjustment coefficient to bring it back to the equilibrium is 25.91 quarterly.

Table 8. Vector Error Correction Model

\begin{tabular}{l|c|c|c|c|c}
\hline Error Correction & D $($ LEXR) & D(LGDP) & D(LCPI) & D(LIR) & D(LM2) \\
\hline CointEq1 coefficient & -0.259 & 0.006 & 0.015 & -0.672 & -0.071 \\
\hline Standard errors & $(0.054)$ & $(0.042)$ & $(0.015)$ & $(0.368)$ & $(0.043)$ \\
\hline t- values & {$[-4.839]$} & {$[0.146]$} & {$[1.017]$} & {$[-1.825]$} & {$[-1.657]$} \\
\hline
\end{tabular}

Standard errors are in ( ) \& t-statistics are in [ ]

VEC Granger causality test

Determining as in the above that variables are cointegrated implies there must be Granger causality in at least one direction. This study uses the VEC Granger Causality/Block Exogeneity Wald Tests. Basing on the probabilities (see appendix 3), it can be seen that there is a two-way causation be GDP and M2 then CPI and M2. There is a one directional causation between GDP and Interest rate, M2 and Exchange rate and Interest rate and CPI/inflation.In terms of collective granger causality (see all), we reject the null hypothesis for GDP, M2 and money interest rate equations

\section{Policy Recommendations}

The paper investigated the determinants of the nominal effective exchange rate of Uganda during the period, 2000-2017. The results showed that inflation, trade of trade and money supply were significant and negatively influencing the nominal effective exchange rate while interest rate and gross domestic product were positive and significant. In light of the above investigation, following policy implications are suggested.

- This study calls for the need to have an anti-inflationary policy since the empirical results indicated the strong negative (depreciation) correlation of inflation and money supply with exchange rate of Uganda. Attempts to decrease the inflation level by stressing strict monetary measures supplemented by tight management of capital inflows which ultimately prevent depreciation of exchange rates

- In order to curb inflation and control money supply, Central Bank of Uganda can also regulate the reserve requirements to restrict banks' ability to create money. If the percentage of deposits which a commercial bank is required to hold is raised, the banks have to hold that amount and thus that money cannot be circulated.

- Restricted import values resulted by increased tariff and duties can improve terms of trade ratios. However, this should be accompanied by emphasis on the improvement of domestic goods industries. Since the present situation of infrastructure of the country is inadequate to instigate the advancement of domestic industry, improvement in power supply, transportation and communication and law and order situation will motivate the confidence of investors and bring prosperity in domestic production.

- Emphasis on export is also required to boost trade liberalization and terms of trade ratios. In order to increase the contribution of exports in openness of the economy, there is a need to compete in global market with strengths of a country. Uganda is a labor-intensive country. There is a need of priority for the production and export of labour demanding products such as textile. This will boost export and encourage reinvestment. Diversification is also a way to have prosperity in the domestic sector.

- The government to keep the three months' interest rate high so that more capital can come in the economy. This would attract more foreign direct investment perhaps resulting into appreciation of the exchange rate. 
- Since neither a depreciation nor an appreciation is all good, it is better for the central bank to make exchange rate more competitive. A depreciation makes exports cheap but since majority of the exports from Uganda are primary commodities and semi-processed good, the export revenue might not improve. This is because we rely on intermediate goods imported from other countries. To create a balance, the government to maintain an optimal exchange rate.

\section{Acknowledgement}

This paper was written during my research fellowship at United Nations Economic Commission for Africa (UNECA) Ethiopia. I am grateful for UNECA for giving me the opportunity to undertake this fellowship. Indeed, I have profited tremendously as I have gained a lot of knowledge and skills during my stay. I am so grateful to my supervisor Joseph Atta- Mensah of UNECA who gave me his most thoughtful professional help, ideas and suggestions that have helped me to develop my skills during this research. I thank Stephen Karingi at UNECA for the intellectual guidance offered during fellowship. I would like to thank my colleagues at UNECA for the help rendered whenever solicited. Lastly I thank the Central Bank of Uganda (BOU) staff especially Louis Kasekende, Thomas Bwire, Charles Abuka, Adam Mugume, Elizabeth Kasekende and Sulaiman Nyanzi for the valuable inputs given during the presentation of the preliminary version of this paper. May God bless u all.

\section{References}

Abuka, C., Alinda, R. K., Minoiu, C., Peydro, J. L., \& Presbitero, A. F. (2015). Monetary Policy in a Developing Country: Loan Applications and Real Effects, IMF working paper, WP/15/270

Bailliu, J., \& King, M. (2005). Understanding what causes the exchange rate to move Bank of Canada Review, 2005, issue Autumn, 27-39.

Balke, N. S., Brown, S. P. A., \& Yücel, M. K. (1999). Oil price shocks and the US economy: Where does the asymmetry originate?, Federal Reserve Bank of Dallas Working Paper, No. 9911.

Blanchard, O., \& Quah, D. (1989). The dynamic effects of aggregate demand and supply disturbances. American Economic review, 79, 655-73.

Bwire, T. J. O., \& Anguyo, F. L. (2013). Exchange rate Pass- Through to Domestic Prices in Uganda: Evidence from a Structural Vector Auto-Regression (SVAR).

Cunado, J., \& de Gracia, F. P. (2003). Do oil price shocks matter? Evidence for some European countries, Energy Economics, 25(2), 137-154. https://doi.org/10.1016/S0140-9883(02)00099-3

Effiong, L. E. (2014). Exchange Rate Dynamics and Monetary Fundamentals: A cointegrated SVAR Approach for Nigeria First Published June 5.

Eryiğit, M. (2009). Effects of oil price changes on the sector indices of Istanbul stock exchange. International Research Journal of Finance and Economics, 25, 209-216.

Eryigit, M. (2012). The dynamic relationship between oil price shocks and macroeconomic variables in Turkey, Economic Research, 25(2), 263-276.

Fleming, J. M. (1962). Domestic Financial Policies under Fixed and under Floating Exchange Rates, IMF Staff Papers.

Gelbard, X., \& Nagayasu, J. (2004). Determinants of Angola's real exchange rate, 1992-2002, Developing Economies XLII(3), 392-404. https://doi.org/10.1111/j.1746-1049.2004.tb00944.x

Jhingan, M. L. (2005). International Economics,5th Edition, Vrinda Publications (P) Limited Delh.

Johansen, S., \& Juselius, K. (1990). Maximum likelihood estimation and inference on cointegration with applications to the demand of money. Oxford Bulletin of Econometrics and Statistics, 52(2), 169-210. https://doi.org/10.1111/j.1468-0084.1990.mp52002003.x

Juselius, K. (2006) The Cointegrated VAR Model: Methodology and Applications, Advanced Texts in Econometrics, Oxford University Press, Oxford.

Kamas, L., \& Joseph, J. (2003). Real and nominal determinants of real exchange rates in Latin America: Short-run dynamics and long-run equilibrium, Journal of Development Studies, 39(6), 155-182. https://doi.org/10.1080/00220380312331293617

Kandil, M. (2004). Exchange rate fluctuations and economic activity in developing countries: Theory and evidence. Journal of Economic Development, 29(1), 85-108.

Khan, R. S. (2014). Analysis If The Factors Affecting Exchange Rate Variability In Pakistan. IOSR Journal Of Business And Management, 115-121. https://doi.org/10.9790/487X-1662115121 
Khattak, N. U. R., Tariq, M., \& Khan, J. (2012). Factors affecting nominal interest rate of Pakistan: An econometric investigation, Asian Economic and Financial Review, 2(2), 421-428.

Kilian, L. (2008). The economic effects of energy price shocks, Journal of Economic Literature, 46(4), 871-909. https://doi.org/10.1257/jel.46.4.871

Kulkarni, K. G., \& Ishizaki, M. (2002). Purchasing power parity theory revisited: Recent evidence from US Dollar and Japanese Yen. Global Business Review, 3(1), 53-61. https://doi.org/10.1177/097215090200300104

Lee, L. S. (2012). Relationship between capital flows and exchange rate in Malaysia.

Mayambala, S. A. (2016). Impact of capital inflows on real exchange rate in Uganda, RUFORUM Trade.

Mendoza, O., \& Vera, D. (2010). The asymmetric effects of oil shocks on an oilexporting economy, Cuadernos De Economia, 47, 3-13. https://doi.org/10.4067/S0717-68212010000100001

Montiel, P. (2013). The Monetary Transmission Mechanism in Uganda, S-43002-UGA-1.

Mugume, A. (2011). Monetary Policy Transmission Mechanisms in Uganda, Bank of Uganda Working Paper Series, BOUWPS/01/2011, Bank of Uganda

Mundel, R. (1963). Capital Mobility and Stabilization Policy under Fixed and Flexible Exchange Rates, Canadian Journal of Economics and Political Science, November 1963. https://doi.org/10.2307/139336

Naeem, R. K., Muhammad, T., \&Jangraiz, K. (2012). Factors Affecting the Nominal Exchange Rate of Pakistan: An Econometric Investigation (1982-2008), Asian Economic and Financial Review, 2(2), 421-428.

Nampewo, D., Munyambonera, E., \& Lwanga, M. M. (2013). Sectoral effects of monetary policy in Uganda, Journal of Statistical and Econometric Methods, 2(4), 17-40.

Noer, A. A. (2010). Estimating a Function of Real Demand for Money inPakistan: An Application of Bounds Testing Approach to Co-integration, International Journal of Computer Applications (0975 -8887), 79(5), October 2013 -32 .

Prema, C. A., \& Sarath, R. (2003). Capital Inflows and the Real Exchange Rate: A Comparative Study of Asia and Latin America, The World Economy, 26(6).

Qianqian, Z. (2011). The impact of international oil price fluctuation on China's economy, Energy Procedia, 5, 13601364. https://doi.org/10.1016/j.egypro.2011.03.235

Raja, S. A. K. (2014). Analysis if the factors affecting exchange rate variability in Pakistan.IOSR Journal of Business and Management (IOSR-JBM), 16(6), Ver. II (Jun. 2014), PP 115-121.

Republic of Uganda. (2017). Ministry of Finance, Planning and Economic Development, Background to the budget.

Sebastian, E. (2003). flexible exchange rates as shock absorbers, NBER working paper series.

Sims, C. (1980). Macroeconomics and Reality, Econometrica, 48(1), 1-48. https://doi.org/10.2307/1912017

Syed, A. R., \& Sahar, A. (2017). Determinants of Exchange Rate in Pakistan: Revisited with Structural Break Testing, Global Business Review, 18(4), 825-848. https://doi.org/10.1177/0972150917692210

Tang, W., Wu, L., \& Zhang, Z. (2010). Oil price shocks and their short- and long-term effects on the Chinese economy, Energy Economics, 32, 3-14. https://doi.org/10.1016/j.eneco.2010.01.002

Taoufik, B., \& Archavin Phisuthtiwatcharavong. (2015). On the determinants of the THB/USD exchange rate; 3rd Economics \& Finance Conference, Rome, Italy, April 14-17, 2015 and 4th Economics \& Finance Conference, London, UK, August 25-28.

United Nations. Economic and Social Council; United Nations. Economic Commission for Africa (1996-09). Exchange rate management policies in Africa: Recent experience and prospects. Addis Ababa: (C) UN.ECA 


\section{Appendix}

Appendix 1. Descriptive statistics

\begin{tabular}{c|c|c|c|c|c|c|c}
\hline & LEXR & LGDP & LCPI & LM2 & LIR & LTOT & LOILPX \\
\hline Mean & 7.646505 & 9.112582 & 4.492412 & 8.243209 & 2.296535 & 4.667314 & 4.040127 \\
\hline Median & 7.552597 & 9.118222 & 4.438870 & 8.238352 & 2.280098 & 4.620432 & 4.104034 \\
\hline Maximum & 8.167716 & 9.605287 & 5.045255 & 9.399725 & 3.096494 & 4.919818 & 4.804222 \\
\hline Minimum & 7.326216 & 8.621227 & 4.029136 & 6.922527 & 1.323312 & 4.479910 & 2.961392 \\
\hline Std. Dev. & 0.215490 & 0.290752 & 0.337136 & 0.797515 & 0.411220 & 0.124489 & 0.551586 \\
\hline Skewness & 0.775886 & -0.086849 & 0.229078 & -0.071689 & -0.089504 & 0.621692 & -0.249504 \\
\hline Kurtosis & 2.607290 & 1.769211 & 1.555760 & 1.576568 & 2.668562 & 2.197245 & 1.745756 \\
\hline & & & & & & & \\
\hline Jarque-Bera & 7.046099 & 4.248788 & 6.313275 & 5.628471 & 0.390210 & 6.023651 & 5.010874 \\
\hline Probability & 0.29509 & 0.119505 & 0.042569 & 0.059951 & 0.822748 & 0.049202 & 0.081640 \\
\hline Sum & & & & & & & \\
\hline Sum Sq. Dev. & 3.018337 & 5.494904 & 7.387942 & 41.34194 & 10.99164 & 1.007342 & 19.77603 \\
\hline Appendix 2. Graph & & & & & &
\end{tabular}

Appendix 2. Graph Variables in levels VS first difference
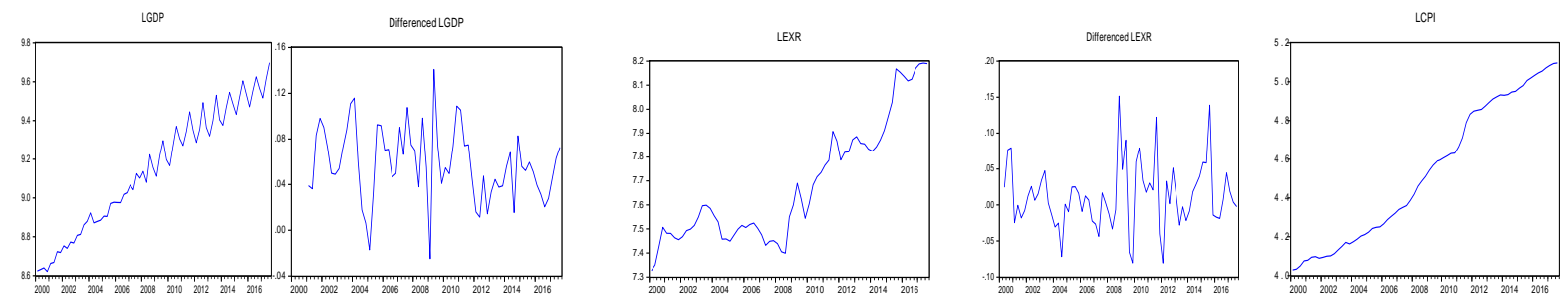

Differerened LPP
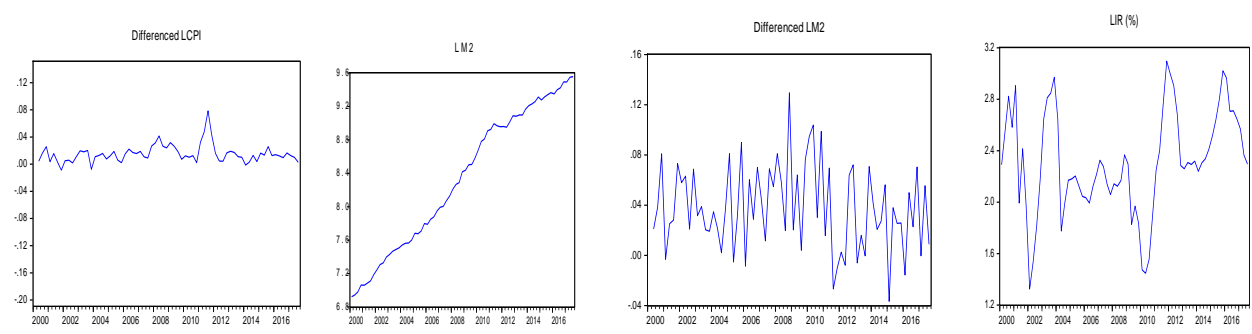

Differenced LR (\%)

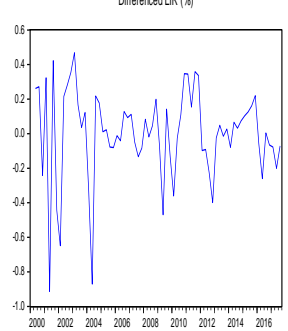

LOIIPX

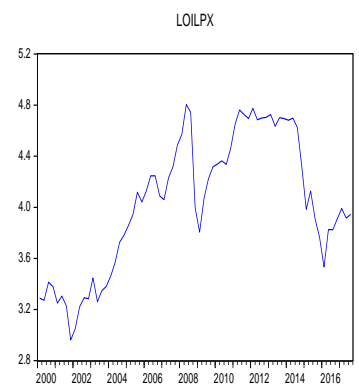

LOILPX

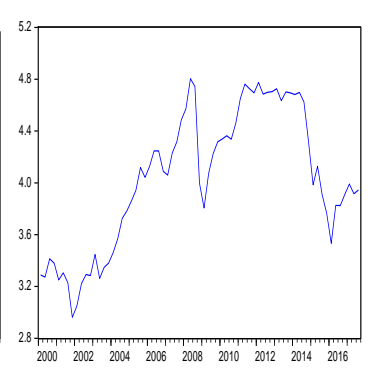

LTOT

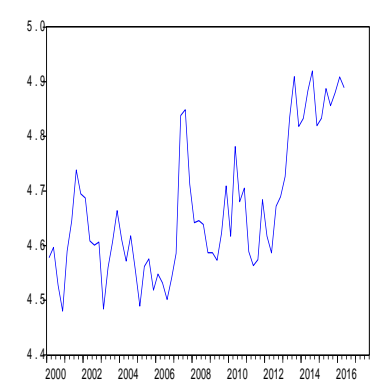

Differenced LTOT

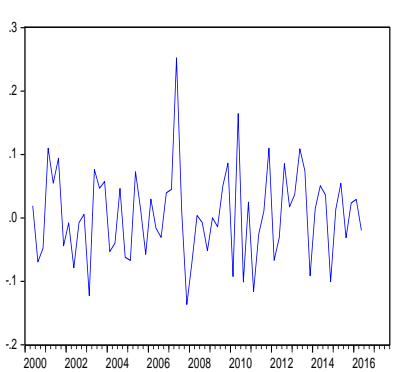


Appendix 3. Granger causality

Table 9. VEC Granger Causality/Block Exogeneity Wald Tests

Dependent variable: D(LEXR)

\begin{tabular}{cccc}
\hline Excluded & Chi-sq & df & Prob. \\
\hline D(LGDP) & 5.699782 & 3 & 0.1272 \\
D(LCPI) & 1.435149 & 3 & 0.6973 \\
D(LIR) & 4.823867 & 3 & 0.1852 \\
D(LM2) & 1.846978 & 3 & 0.6048 \\
\hline All & 14.34698 & 12 & 0.2791 \\
\hline
\end{tabular}

Dependent variable: D(LGDP)

\begin{tabular}{cccc}
\hline Excluded & Chi-sq & df & Prob. \\
\hline D(LEXR) & 0.671726 & 3 & 0.8798 \\
D(LCPI) & 4.358991 & 3 & 0.2252 \\
D(LIR) & 6.499320 & 3 & 0.0897 \\
D(LM2) & 13.75942 & 3 & 0.0033 \\
\hline All & 25.89856 & 12 & 0.0111 \\
\hline
\end{tabular}

Dependent variable: D(LCPI)

\begin{tabular}{cccc}
\hline Excluded & Chi-sq & df & Prob. \\
\hline D(LEXR) & 1.504401 & 3 & 0.6813 \\
D(LGDP) & 2.038821 & 3 & 0.5644 \\
D(LIR) & 1.458147 & 3 & 0.6920 \\
D(LM2) & 12.37697 & 3 & 0.0062 \\
\hline All & 16.99914 & 12 & 0.1496 \\
\hline
\end{tabular}

Dependent variable: D(LIR)

\begin{tabular}{cccc}
\hline Excluded & Chi-sq & df & Prob. \\
\hline D(LEXR) & 2.014687 & 3 & 0.5694 \\
D(LGDP) & 3.225691 & 3 & 0.3581 \\
D(LCPI) & 9.465581 & 3 & 0.0237 \\
D(LM2) & 2.519749 & 3 & 0.4717 \\
\hline All & 21.05917 & 12 & 0.0495 \\
\hline
\end{tabular}

Dependent variable: D(LM2)

\begin{tabular}{cccc}
\hline Excluded & Chi-sq & df & Prob. \\
\hline D(LEXR) & 11.38538 & 3 & 0.0098 \\
D(LGDP) & 6.788490 & 3 & 0.0790 \\
D(LCPI) & 6.445770 & 3 & 0.0918 \\
D(LIR) & 3.828182 & 3 & 0.2806 \\
\hline All & 29.38641 & 12 & 0.0035 \\
\hline
\end{tabular}

H0: There is no granger causality 
Appendix 4. Impulse response functions
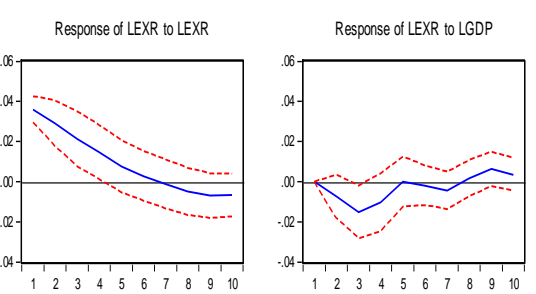

Response to Cholesky One S.D. Innovations \pm 2 S.E

Response of LEXR to LCPI
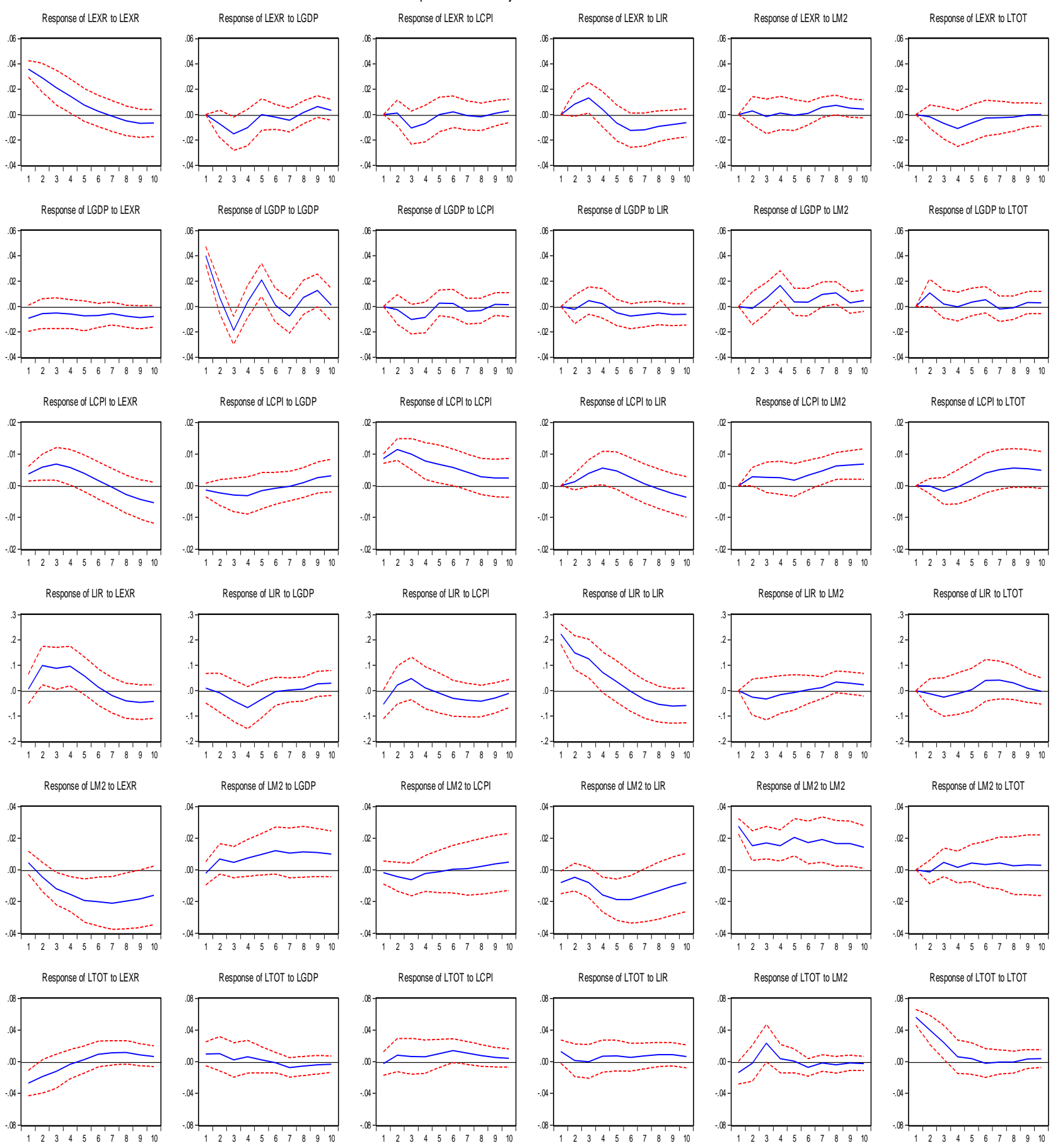

\section{Copyrights}

Copyright for this article is retained by the author(s), with first publication rights granted to the journal.

This is an open-access article distributed under the terms and conditions of the Creative Commons Attribution license which permits unrestricted use, distribution, and reproduction in any medium, provided the original work is properly cited. 